\title{
Growth Arrest-Specific Protein 2
}

National Cancer Institute

\section{Source}

National Cancer Institute. Growth Arrest-Specific Protein 2. NCI Thesaurus. Code C29594.

Growth arrest-specific protein 2 (313 aa, $35 \mathrm{kDa}$ ) is encoded by the human GAS2 gene.

This protein may be involved in both apoptosis and cytoskeletal rearrangement. 